\title{
Photothermal therapy of cancer cells using novel hollow gold nanoflowers
}

\author{
This article was published in the following Dove Press journal: \\ International Journal of Nanomedicine \\ 16 January 2014 \\ Number of times this article has been viewed
}

\author{
Jing $\operatorname{Han}^{\prime}$ \\ Jinru Li' \\ Wenfeng Jia' \\ Liangming $\mathrm{YaO}^{2}$ \\ Xiaoqin $\mathrm{Li}^{\prime}$ \\ Long Jiang' \\ Yong Tian ${ }^{2}$
}

'Beijing National Laboratory for Molecular Sciences, Institute of Chemistry, ${ }^{2}$ Beijing Key Laboratory of Noncoding RNA, Institute of Biophysics, Chinese Academy of Sciences, Beijing, People's Republic of China
Correspondence: Long Jiang/Yong Tian Beijing National Laboratory for Molecular Sciences, Institute of Chemistry, Chinese Academy of Sciences, 2 First North Street, Zhongguancun, Beijing 100190 , People's Republic of China

Tel +86 I0 826I 2084

Fax +86 I0 826I 2084

Email jiangl@iccas.ac.cn
Abstract: This article presents a new strategy for fabricating large gold nanoflowers (AuNFs) that exhibit high biological safety under visible light and very strong photothermal cytotoxicity to HeLa cells under irradiation with near-infrared (NIR) light. This particular type of AuNF was constructed using vesicles produced from a multiamine head surfactant as a template followed by depositing gold nanoparticles (AuNPs) and growing their crystallites on the surface of vesicles. The localized surface plasmon-resonance spectrum of this type of AuNF can be easily modulated to the NIR region by controlling the size of the AuNFs. When the size of the AuNFs increased, biosafety under visible light improved and cytotoxicity increased under NIR irradiation. Experiments in vitro with HeLa cells and in vivo with small mice have been carried out, with promising results. The mechanism for this phenomenon is based on the hypothesis that it is difficult for larger AuNFs to enter the cell without NIR irradiation, but they enter the cell easily at the higher temperatures caused by NIR irradiation. We believe that these effects will exist in other types of noble metallic NPs and cancer cells. In addition, the affinity between AuNPs and functional biomolecules, such as aptamers and biomarkers, will make this type of AuNF a good recognition device in cancer diagnosis and therapy.

Keywords: HeLa cells, endocytosis, cytotoxicity, AuNFs, NIR, cancer therapy

\section{Introduction}

In the nanotechnology field, the use of nanoscale materials in medicine is one of the most important research areas. Recently, numerous nanoscale materials with various components, morphologies, and sizes have been used in drug delivery, bioimaging, chemical sensing, early cancer cell diagnostics, and therapeutics. ${ }^{1-11}$ Among these applications, photothermal therapy has attracted increased attention. The laserwavelength region used in this method is often located in the near-infrared (NIR) region at approximately $800-1,200 \mathrm{~nm}$, where the transparent window for biological tissues is located. In general, photothermal therapy depends on the photosensitizers taken up by cancer cells to transfer light to heat, leading to photoablation of the cells and subsequent cell death. Therefore, photosensitizing agents are a key factor in photothermal therapy. Among the numerous photosensitizers, gold nanoparticles (AuNPs) are a special photosensitizer in that they exhibit strong localized surface plasmon resonance (LSPR). Many types of Au nanomaterials, such as nanorods, nanocages, and nano-core-shells, have been reported as photosensitizers in photothermal therapy. ${ }^{2,4,10,12,13-16}$ Furthermore, flower-like and core-shell gold nanostructure have been reported to have obvious advantages over spheres and rods of nanogold in the NIR absorption. ${ }^{9,17}$ For example, Oldenburg et $\mathrm{al}^{14}$ reported the fabrication of $\mathrm{SiO}_{2} @ \mathrm{Au}$ structures and their application in 
cancer therapy. ${ }^{15}$ Furthermore, Kim et al modified Oldenburg et al's synthesis procedure to synthesize magnetic gold nanoshells consisting of gold nanoshells embedded with magnetic $\mathrm{Fe}_{3} \mathrm{O}_{4} \mathrm{NPs}$, which were conjugated with a cancer-targeting agent. ${ }^{8}$ In addition, PS@Au core-shell nanostructures with NIR absorption were fabricated and used for photothermal therapy of Lewis lung carcinoma. ${ }^{16}$ However, avoidable problems are associated with these core-shells with solid core materials in the context of future practical application, such as the biocompatibility and retention of solid core in the body. In addition to this, the complicated and tedious procedure of fabricating such structures greatly hinders the application of these gold nanostructures in medicine. ${ }^{18,19}$ Therefore, to meet the requirement of practical application, large, core-free, hollow gold shells with good NIR absorption are desired.

In this work, a novel and facile construction of hollow gold nanoflowers (AuNFs) is presented. It is dependent on vesicles of a new tree-type surfactant - bis(amidoethylcarbamoylethyl) octadecylamine (C18N3) - with multiamine head groups. The results of the experiment indicated that the absorption peak of AuNFs can be tuned easily from the visible to the NIR region through controlling the size of AuNFs. Furthermore, AuNFs can be used as efficient photothermal agents in the application of cancer therapy. The advantage of these AuNFs is their low toxicity to cells due to their large size, which reduces their uptake by cells. ${ }^{18,20}$ In addition to this, AuNFs exhibit a very strong photothermal effect even at small doses, resulting in obvious photothermal ablation of the HeLa cells.

\section{Materials and methods Materials}

Chloroauric acid $\left(\mathrm{HAuCl}_{4} \cdot 4 \mathrm{H}_{2} \mathrm{O}\right)$, ascorbic acid (AA), and sodium citrate were purchased from Beijing Chemical Industry (Beijing, People's Republic of China). Ultrapure deionized water (Milli-Q, $\mathrm{M} \Omega \cdot \mathrm{cm}^{-1}$; Merck Millipore, Billerica, MA, USA) was used for all solution preparations. HeLa cell lines were purchased from the American Type Culture Collection (Manassas, VA, USA). Dulbecco's Modified Eagle's Medium (DMEM) without phenol red, phosphate-buffered saline (PBS; 0.01 M, pH 7.4), newborn calf (NC) serum, and trypsinase were obtained from Life Technologies (Carlsbad, CA, USA).

\section{Preparation of Au hollow nanoflowers}

C18N3 (0.425 g) was dissolved in $25 \mathrm{~mL}$ of water. For rapid and improved dissolution, the solution was placed in an ultrasonic bath for 5 minutes. Then, the $\mathrm{pH}$ value of the C18N3 solution was adjusted using a $0.1 \mathrm{M} \mathrm{HCl}$ solution, and the $\mathrm{pH}$ value was measured with a HI $8314 \mathrm{pH}$ meter (Hanna Instruments, Woonsocket, RI, USA) equipped with an HI 1200B glass electrode. When the $\mathrm{pH}$ value of the C18N3 solution reached 3, the solution became transparent, indicating the formation of micelles. Next, $5 \mathrm{~mL}$ of a citrate-protected AuNP ( $24 \mathrm{~nm}$ in diameter, absorption peak at $520 \mathrm{~nm}$ ) solution was added. The mixture was stirred at room temperature overnight as a seed solution for the AuNFs. In addition, a $0.5 \mathrm{mM} \mathrm{C} 18 \mathrm{~N} 3$ solution containing $0.25 \mathrm{mM}$ chloroauric acid $\left(\mathrm{HAuCl}_{4} \cdot 4 \mathrm{H}_{2} \mathrm{O}\right)$ was prepared in a $100 \mathrm{~mL}$ volumetric flask as the growth solution for the AuNFs. Next, hollow AuNFs were prepared by adding $2.5 \mathrm{~mL}$ of the seed solution containing $\mathrm{C} 18 \mathrm{~N} 3$ and $24 \mathrm{~nm}$ AuNPs to $100 \mathrm{~mL}$ of the growth solution containing $0.5 \mathrm{mM} \mathrm{C} 18 \mathrm{~N} 3$ and $0.25 \mathrm{mM}$ chloroauric acid. Then, the mixture was gently agitated. After nearly 30 seconds, $350 \mu \mathrm{L}$ of an AA aqueous solution $(0.1 \mathrm{M})$ was added, followed by gentle stirring of the mixture. The mixture was maintained at room temperature overnight. After the reaction, the AuNFs were purified by centrifugation several times at $8,000 \mathrm{rpm}$ for 5 minutes to remove the unbound $\mathrm{C} 18 \mathrm{~N} 3$ and citrate.

\section{Characterization of AuNFs}

The morphology of the samples was determined by scanning electron microscopy (SEM) (S4800; Hitachi, Tokyo, Japan). The ultraviolet-visible (UV-vis) spectra of colloidal AuNPs were tested in a 2 mm-thick quartz cell using a Hitachi U-2800 spectrometer. Dynamic light-scattering characterization of hydrodynamic diameter was carried out at $25^{\circ} \mathrm{C}$ and a scattering angle of $173^{\circ}$ by ZetaSizer Nano Series Nano ZS (Malvern Instruments, Malvern, UK) equipped with a thermostated chamber, employing a $4 \mathrm{~mW} \mathrm{He}-\mathrm{Ne}$ laser $(\lambda=632.8 \mathrm{~nm})$. For SEM measurement, all samples were measured after at least 50 hours to ensure the crystallite growth of AuNFs was completed. First, the AuNFs were purified by centrifugation three times at $8,000 \mathrm{rpm}$ for 5 minutes to remove unbound $\mathrm{C} 18 \mathrm{~N} 3$ and citrate. Next, the suspension of AuNFs was placed on a silicon wafer, followed by air-drying.

\section{Evaluation of biocompatibility of AuNFs}

HeLa cell lines were cultured in DMEM containing 10\% NC serum at $37^{\circ} \mathrm{C}$ under $5 \% \mathrm{CO}_{2}$. The cell-culture media were supplemented with penicillin and streptomycin. The HeLa cells (10,000 cells per well) were seeded in 96-well plates for 24 hours to allow the cells to attach to the surface of the well. 
Next, the NPs were introduced to the 96-well plates in various concentrations. After incubation with NPs for 24 hours at $37^{\circ} \mathrm{C}$ under $5 \% \mathrm{CO}_{2}$, cell viability was determined using a cell-counting kit (CCK-8; Dojindo Laboratories, Kumamoto, Japan). Cells that were not exposed to AuNPs were regarded as controls. Cell viability was calculated as the ratio of the absorbance of the treated and control wells.

\section{In vitro photothermal experiment}

HeLa cell lines were cultured in DMEM containing 10\% NC serum at $37^{\circ} \mathrm{C}$ under $5 \% \mathrm{CO}_{2}$. The HeLa cells $(10,000$ cells per well) were seeded in 96-well plates for 24 hours to allow the cells to attach to the surface of the well. The cell-culture media were supplemented with penicillin and streptomycin. Next, the AuNFs were introduced to 96-well plates in various concentrations. After incubation of the cells with AuNFs for 4 hours at $37^{\circ} \mathrm{C}$, the growth medium was removed, and the cells were washed several times with PBS to remove the free AuNFs that were not taken up by the cells. Subsequently, the cells were exposed to a continuous red light laser at $808 \mathrm{~nm}$ $\left(9 \mathrm{~W} / \mathrm{cm}^{2}\right)$ for 5 minutes. After incubation for 24 hours at $37^{\circ} \mathrm{C}$, cell viability was determined using the CCK-8. Cells exposed to the red light laser but unexposed to AuNFs were regarded as controls. Cell viability was calculated as the ratio of the absorbance of the treated and control wells.

\section{In vivo photothermal therapy}

Female Balb/c mice that were $4-5$ weeks old were maintained under standard housing conditions. HeLa tumor-bearing mice were established by subcutaneous injection of $1 \times 10^{7}$ cells suspended in $100 \mu \mathrm{L}$ PBS into the flank region. The longest dimension and the shortest dimension of the tumors were monitored using a Vernier caliper. Once the tumors were $\sim 7.0 \mathrm{~mm}$ in the longest dimension, the mice were randomized into two treatment groups (five animals per treatment group), where one group did not receive AuNFs and the other group received AuNFs $(40 \mu \mathrm{L}, 2 \mathrm{mg} / \mathrm{mL}$ AuNF solution, AuNF NIR group). The mice were administered the AuNFs intratumorally, followed by irradiation of the tumors with an $808 \mathrm{~nm}$ continuous-wave NIR laser at $5 \mathrm{~W} / \mathrm{cm}^{2}$ for 3 minutes after the mice were anesthetized.

\section{Transmission electron microscope analysis of AuNF-cell interaction}

HeLa cells were seeded at a density of $2 \times 10^{6}$ cells/well into petri dishes (diameter $35 \mathrm{~mm}$ ) filled with the appropriate culture medium. After adherence for 24 hours, the cells were treated with the AuNFs at different concentrations, or not adding AuNFs as the control. After 24 hours, the adherent cells were removed by trypsinization and washed twice with $0.01 \mathrm{M}$ PBS. The cell pellets were fixed in $2.5 \%$ glutaraldehyde in $0.01 \mathrm{M}$ PBS (pH 7.4) at $4^{\circ} \mathrm{C}$ for at least 4 hours. The cells were then rinsed with cold 0.01 M PBS and postfixed in $1 \%$ osmium tetroxide at room temperature for another 2 hours. After dehydration with an acetone gradient (15 minutes' incubation each in 30\%, 50\%, 70\%, 80\%, $90 \%$, and $100 \%$ acetone), the samples were embedded in epoxy resin (Spurr; Sigma-Aldrich, St Louis, MO, USA) and acetone $(1: 1 \mathrm{v} / \mathrm{v})$ for 30 minutes, followed by $100 \%$ Spurr epoxy resin for 1 hour. Finally, the epoxy resin was solidified by incubation at $37^{\circ} \mathrm{C}$ for 24 hours and at $60^{\circ} \mathrm{C}$ for another 48 hours. Ultrathin sections, obtained with an ultramicrotome (UC6i; Leica Microsystems, Wetzlar, Germany) were stained with uranyl acetate and lead citrate. The cells were observed by transmission electron microscope (JEM 1230; JEOL, Tokyo, Japan) after the aforementioned pretreatment at an accelerated voltage of $80 \mathrm{kV}$.

\section{Results and discussion Microscopic characterization and optical properties of AuNF structures}

In our studies, AuNFs were prepared according to previously published protocols. ${ }^{21,22}$ The synthesis procedure is shown in Figure 1. A multiamine surfactant (C18N3), which was synthesized in our laboratory, was used as a template for the formation of AuNFs. Firstly, the vesicle of C18N3 was formed through modulating the $\mathrm{pH}$ of $\mathrm{C} 18 \mathrm{~N} 3$ aqueous solution $(5 \mathrm{mM}, \mathrm{pH}=3)$ and adding small AuNPs to form a seed solution of AuNFs. Subsequently, the obtained seed solution of AuNFs was grown in a crystallite growth solution containing $\mathrm{HAuCl}_{4}, \mathrm{C} 18 \mathrm{~N} 3$, and a reductant (AA), which had a concentration of $0.35 \mathrm{mM}$. Typically, we used the $\mathrm{C} 18 \mathrm{~N} 3$ aqueous solution as a starting working solution. Next, AuNPs that were $24 \mathrm{~nm}$ in diameter were added as seeds which attaching to the vesicle surface to form the original AuNFs. Then, the size of the AuNFs was regulated by adding the original AuNFs to the crystallite growth solution containing $\mathrm{HAuCl}_{4}, \mathrm{C} 18 \mathrm{~N} 3$, and AA $(0.35 \mathrm{mM})$ reductant. Figure 2 shows that the diameters of the AuNFs were mediated by varying the concentration of the crystallite growth solution component at a fixed $\mathrm{HAuCl}_{4} / \mathrm{C} 18 \mathrm{~N} 3$ molar ratio of 2 . This result shows that as the concentration of the growth solution increased, the morphology of the products exhibited almost no change, but the size of the products increased. This result was in qualitative agreement with the dynamic light-scattering measurements (Figure S1). 


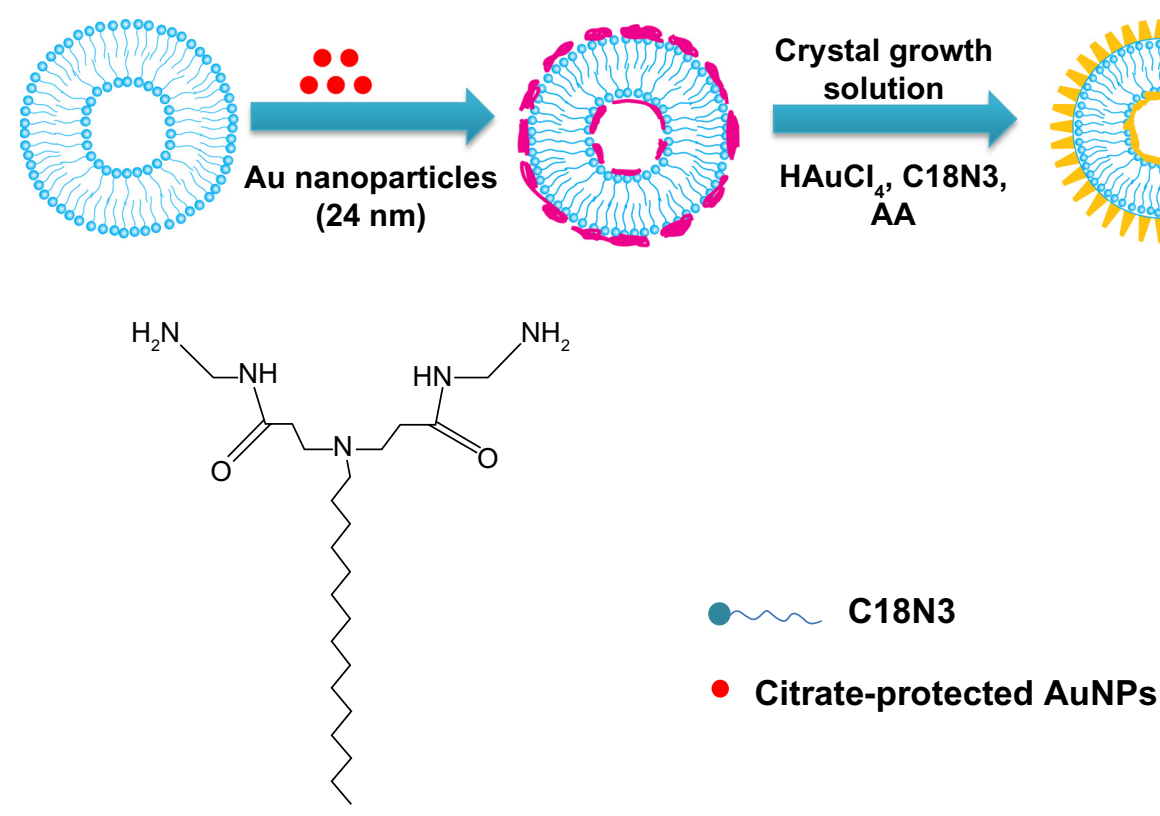

\section{Molecular structure of C18N3}

Figure I Schematic representation showing the fabrication procedure of the Au nanoflowers (AuNFs) employed in the current study. Abbreviation: $\mathrm{AA}$, ascorbic acid.

According to these results, the four types of products were denoted as AuNFs (115 nm), AuNFs (126 nm), AuNFs $(145 \mathrm{~nm})$, and AuNFs $(153 \mathrm{~nm})$. These results demonstrated that the size of the AuNFs was easily controlled by changing the component concentrations in the crystallite growth solution. UV-vis measurements were employed to examine the relationship between the growth process and

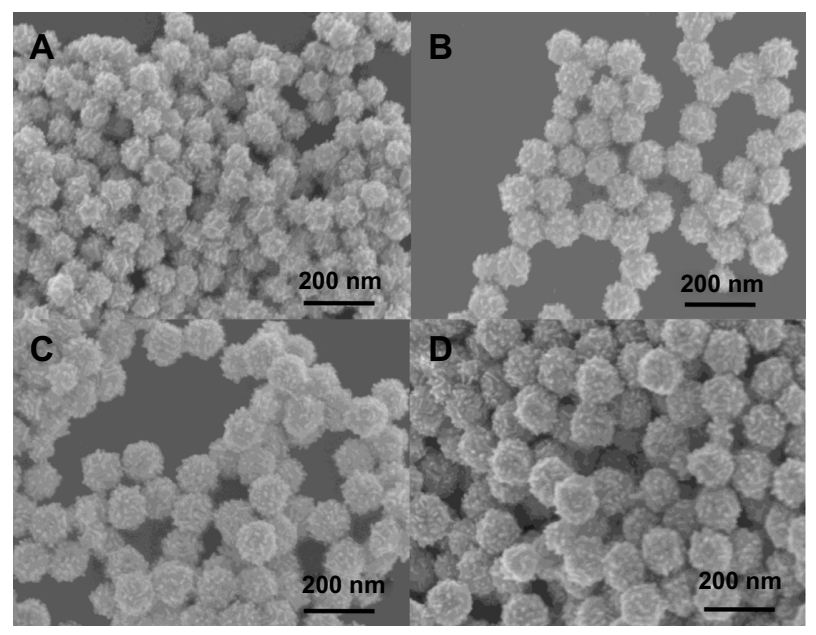

Figure 2 (A-D) Scanning electron microscopy images of the Au nanoflowers (AuNFs) after adding the initial AuNFs to the different growth solutions for more than 24 hours. The crystallite growth solution consisted of varying concentrations of bis(amidoethylcarbamoylethyl) octadecylamine $(\mathrm{Cl} 8 \mathrm{~N} 3)$ and $\mathrm{HAuCl}_{4}$. The ratio of $\mathrm{C}_{\mathrm{HAuCl}_{4}} / \mathrm{C}_{\mathrm{Cl} \text { I8N3 }}$ was 2 , and the concentration of the reducing agent, ascorbic acid $(0.35 \mathrm{mM})$, was fixed. The concentrations of $\mathrm{Cl} 8 \mathrm{~N} 3$ and $\mathrm{HAuCl}_{4}$ were as follows: $(\mathbf{A}) \mathrm{C}_{\mathrm{Cl} \mid 8 \mathrm{~N} 3}=0.0625 \mathrm{mM}$, $\mathrm{C}_{\mathrm{HAUCl}_{4}}=0.125 \mathrm{mM}$; (B) $\mathrm{C}_{\mathrm{CI8N3}}=0.125 \mathrm{mM}, \mathrm{C}_{\mathrm{HAuCl}_{4}}=0.25 \mathrm{mM}$; (C) $C_{\mathrm{CI8N3}}=0.1875 \mathrm{mM}$, $\mathrm{C}_{\mathrm{HAuCl}_{4}}=0.375 \mathrm{mM}$; and (D) $\mathrm{C}_{\mathrm{Cl}_{8 N 3}}=0.25 \mathrm{mM}, \mathrm{C}_{\mathrm{HAuCl}_{4}}=0.5 \mathrm{mM}$. the LSPR spectra shift of AuNFs, and the dynamics of the LSPR spectra shift for different-size AuNFs are shown in Figure 3. The increase in the AuNF size resulted in a longer wavelength in the NIR. The results revealed that the LSPR spectra were easily mediated by changing the size of the AuNFs in our experiment.

\section{Photothermal conversion experiments of AuNFs under NIR light irradiation}

To understand the photothermal transfer dynamics of this type of AuNF, experiments were performed to measure the temperature increase caused by the size and concentration of the AuNFs under NIR irradiation. Figure 4 indicates the temperature increase $(\Delta T)$ for different sizes of AuNFs at various concentrations with time. Four samples - AuNFs (115 nm), AuNFs (126 nm), AuNFs (145 nm), and AuNFs (153 nm) were used in this experiment. All of these AuNFs exhibited a very strong photothermal effect under NIR irradiation. The AuNFs that were larger showed a noticeable increase in the strength of the photothermal effect. For example, at a concentration of $2 \mathrm{mg} / \mathrm{mL}$ of AuNFs $(153 \mathrm{~nm})$, the $\Delta T$ values were a maximum of approximately $70^{\circ} \mathrm{C}$ for less than 10 minutes at an irradiation power density of $9 \mathrm{~W} / \mathrm{cm}^{2}$. In comparison, the $\Delta T$ values of the PBS solution without AuNFs, which was used as a control, were less than $4^{\circ} \mathrm{C}$. This result indicated that the larger AuNFs resulted in a stronger photothermal effect, which was attributed to the 

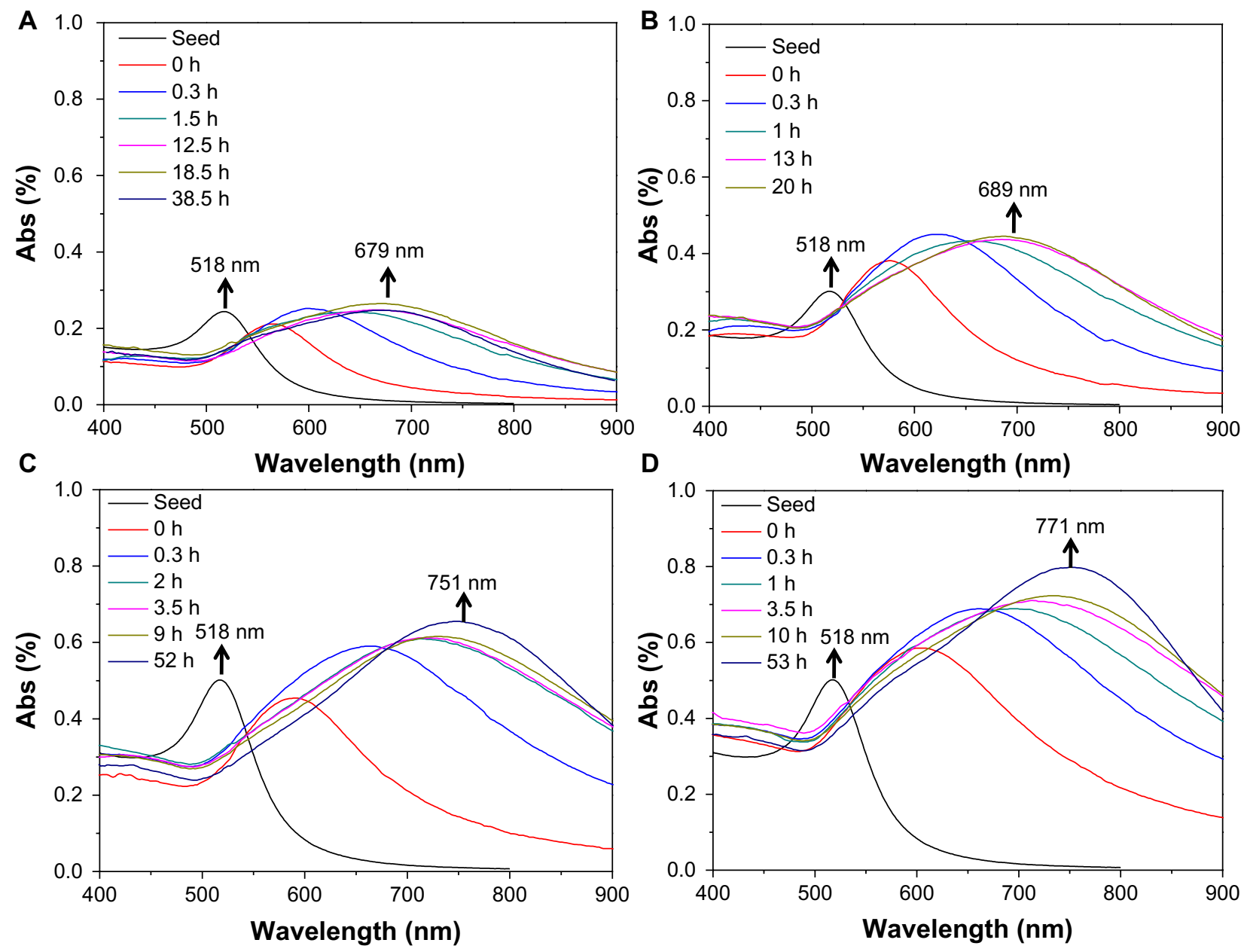

Figure 3 (A-D) The dynamics of the localized surface plasmon-resonance spectra shift for different sizes of Au nanoparticles. The average sizes of the Au nanoflowers were (A) $115 \mathrm{~nm}$, (B) $126 \mathrm{~nm}$, (C) $145 \mathrm{~nm}$, and (D) $153 \mathrm{~nm}$.

better absorption in the NIR region and the high purity of the gold in this type of AuNF.

\section{Interaction of AuNFs and HeLa cells under visible light and NIR light irradiation}

The in vitro toxicity of AuNFs to cells must first be evaluated to determine if they are an appropriate photothermal agent for use in cancer therapy. In this study, the AuNFs were incubated with HeLa cells without NIR irradiation for 24 hours, and measurement of cell viability was conducted using the CCK-8. There was no observed decrease in cell viability from these results (Figure 5A). All AuNFs showed good biocompatibility with cell viability more than $90 \%$ for a particle concentration of up to $2 \mathrm{mg} / \mathrm{ml}$. For the largest AuNFs, the viability of the HeLa cells was better than the small ones, which indicated that under ordinary visible light, no AuNFs were harmful to the HeLa cells, even at a relatively high concentration.
Then, we used the AuNFs for photothermal ablation of cancer cells. HeLa cells were incubated with the four types of AuNF $(10 \mu \mathrm{L})$ with concentrations at $0 \mathrm{mg} / \mathrm{mL}$, $0.4 \mathrm{mg} / \mathrm{mL}, 0.6 \mathrm{mg} / \mathrm{mL}, 1 \mathrm{mg} / \mathrm{mL}$, and $2 \mathrm{mg} / \mathrm{mL}$ for 4 hours. Then, the cells were washed several times with PBS to remove the excess AuNFs in the medium. Next, these samples were exposed to an $808 \mathrm{~nm}$ NIR laser with a power density of $9 \mathrm{~W} / \mathrm{cm}^{2}$ for 5 minutes. A standard cell-viability assay using CCK-8 as an indicator was performed to determine the relative viabilities of the HeLa cells after irradiation for 24 hours. As shown in Figure 5B, the viability of the cells treated with AuNFs $(115 \mathrm{~nm})$ and AuNFs $(126 \mathrm{~nm})$ began to substantially decrease when the concentration of the AuNFs reached $1 \mathrm{mg} / \mathrm{mL}$. The viability of the cells treated with larger AuNFs (126 nm) was approximately $27.13 \%$, which was significantly lower than the $77.7 \%$ induced by AuNFs (115 nm). For AuNFs $(146 \mathrm{~nm})$ and AuNFs $(153 \mathrm{~nm})$, the decrease in cell viability was even more obvious. This result is 

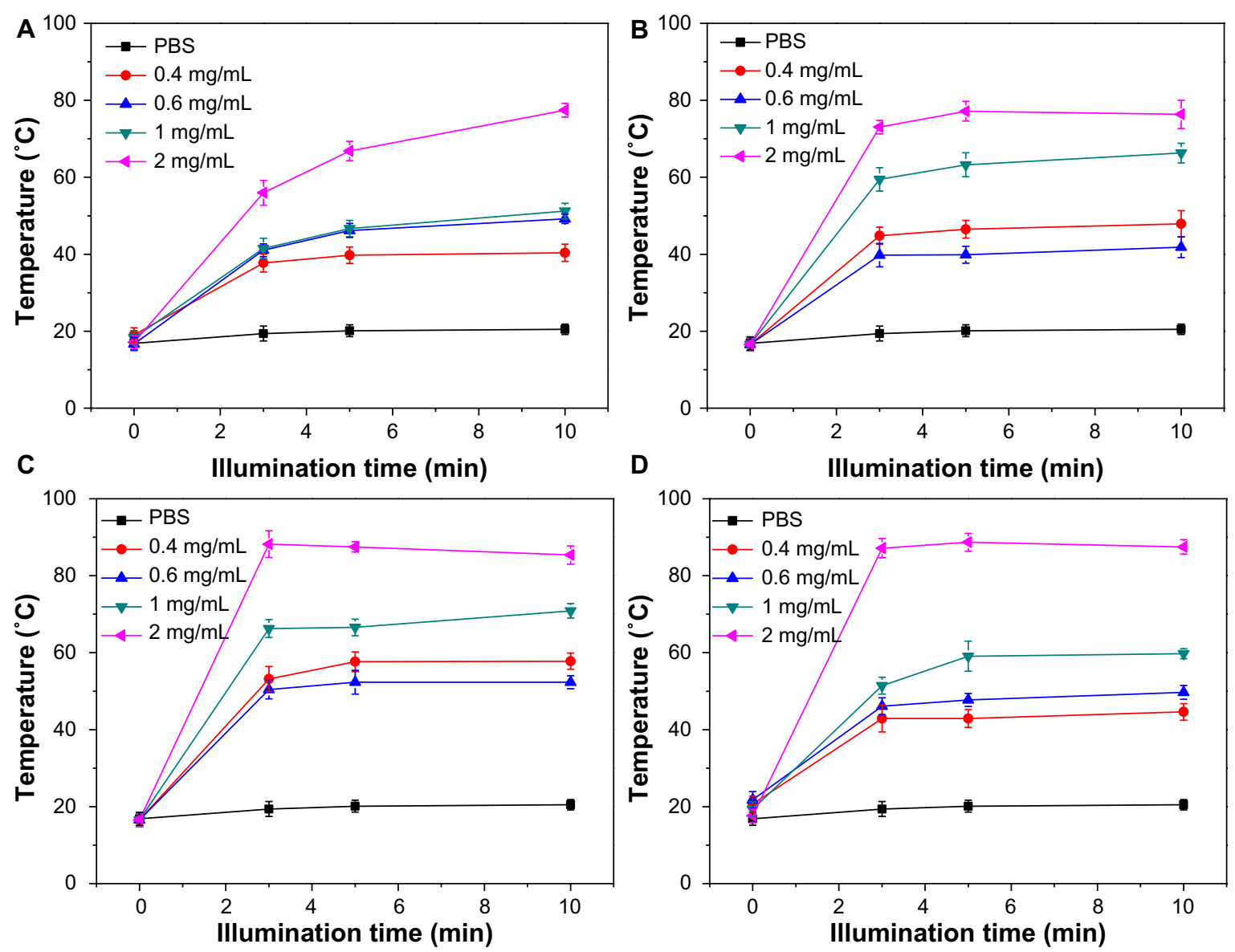

Figure 4 (A-D) Dynamics of the temperature increase for different sizes and concentrations of Au nanoflowers (AuNFs) in phosphate-buffered saline (PBS) under nearinfrared irradiation. The average sizes of the AuNFs were approximately (A) $115 \mathrm{~nm}$, (B) $126 \mathrm{~nm}$, (C) $145 \mathrm{~nm}$, and (D) I53 nm.

consistent with results of UV-vis spectra and photothermal conversion experiments. In the UV-vis spectra experiment, as AuNFs get bigger, the LSPR peak remarkably shifts to longer wavelengths (Figure 3) and closer to $808 \mathrm{~nm}$. For the photothermal conversion experiment, all kinds of

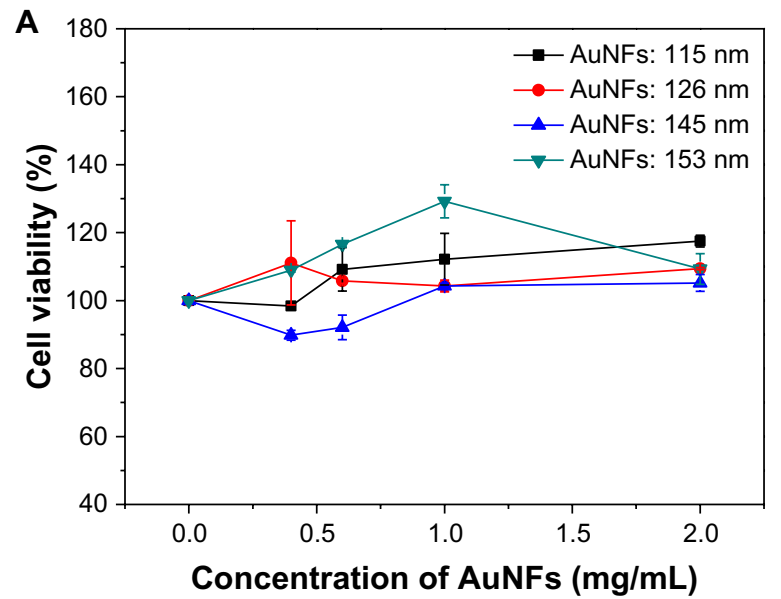

AuNF could convert laser energy to heat: larger, higherconcentration AuNFs induced temperature increased faster and higher. As we know, tumor cells can be killed at $42^{\circ} \mathrm{C}-43{ }^{\circ} \mathrm{C} .{ }^{16}$ The results shown in Figures 4 and $5 \mathrm{~B}$ are consistent with this. Because the AuNFs (153 nm) were

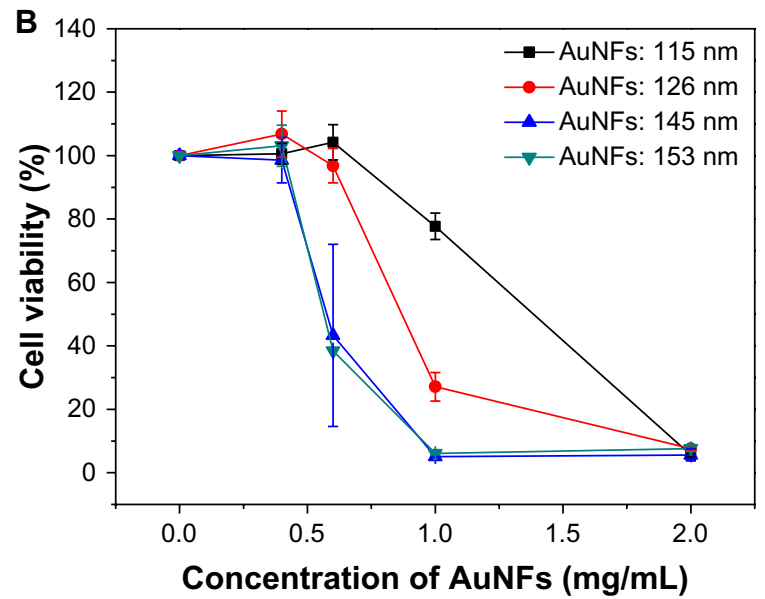

Figure 5 Relationship between the HeLa cell viabilities and the concentration of Au nanoflowers (AuNFs) (A) without laser irradiation and (B) with laser irradiation $\left(\lambda=808 \mathrm{~nm}, 9 \mathrm{~W} / \mathrm{cm}^{2}, 5\right.$ minutes). The average sizes of the AuNFs were (a) II $\mathrm{nm}$, (b) $126 \mathrm{~nm},(\mathbf{c}) 145 \mathrm{~nm}$, and (d) I53 nm. 


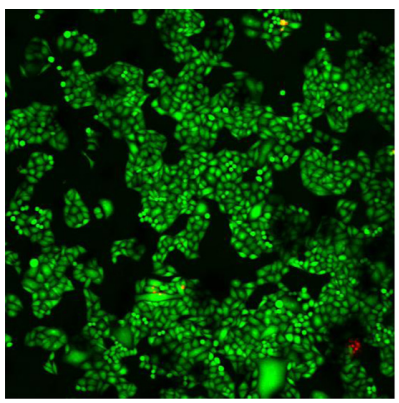

Under NIR irradiation without AuNFs

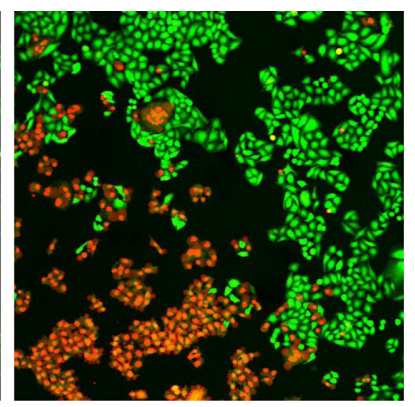

Under NIR irradiation with AuNFs
Figure 6 Fluorescence microscopy images of HeLa cells under different treatment conditions and stained with calcein acetoxymethyl ester and propidium iodide. The green and red areas represent the regions of living and dead cells, respectively. Concentration of $\mathrm{Au}$ nanoflowers (AuNFs), $0.6 \mathrm{mg} / \mathrm{mL}$; near-infrared (NIR) laser, $\lambda=808 \mathrm{~nm}, 9 \mathrm{~W} / \mathrm{cm}^{2}, 5$ minutes; image size $1.3 \times 1.3 \mathrm{~cm}$ and under-irradiation area $0.4 \mathrm{~cm}^{2}$.

the best photothermal agent, they were used in most of our subsequent experiments.

Fluorescence microscopy was employed to prove further the photothermal ablation of HeLa cells induced by the AuNFs. After NIR laser treatment, the cells were incubated with calcein acetoxymethyl ester (AM) and propidium iodide (PI) to separately stain viable cells and dead cells. A green fluorescence color caused by calcein AM indicates viable cells, and a red fluorescence color caused by PI indicates dead cells. As shown in Figure 6, the AuNF (153 nm)treated HeLa cells had a significant loss of viability under NIR irradiation, whereas the cells in the control experiment exhibited no ablation.

Figure 7 shows the electron micrographs for the internalization of AuNFs by HeLa cells. Figure 7A shows the control samples in which no AuNFs were added. Figure 7B shows that a small portion of the AuNFs $(153 \mathrm{~nm})$ entered the cells and aggregated slightly under irradiation by ordinary visible light. Figure 7C shows that many AuNFs entered the
HeLa cells and aggregated under NIR irradiation. Almost no AuNFs were observed in the cell nucleus. However, the AuNFs were primarily distributed in the cytoplasm and mitochondria.

\section{Photothermal therapy of AuNFs in vivo}

To study further the photothermal effect of AuNFs, an in vivo photothermal experiment in mice was conducted under NIR. Figure 8 shows that the tumors in mice that were treated with the control solution (ie, no AuNFs were added) increased in size. However, the tumors in mice treated with solutions containing AuNFs almost disappeared in lesion after 20 days. All of the experimental mice maintained their weight during the therapy process, as observed in Figure 8C, which indicated that no fatal toxicity was induced by the treatment. The result from the animal experiment indicated that the AuNFs have a promising future for the photothermal therapy of cancer. However, this was just a preliminary study on photothermal therapy of AuNFs in mice, and more detailed biological evaluations are required to improve this system.

To understand the cytotoxicity mechanism of AuNFs, the endocytosis of cells affected by size and temperature is important. Previous investigations of cell endocyto$\operatorname{sis}^{18,20}$ have reported that small AuNPs $(<50 \mathrm{~nm})$ will be internalized more easily by cells. We have also reported ${ }^{23}$ that AuNPs cause cell death when they penetrate the cells, while AuNPs outside the cell are often not harmful. Jia et $\mathrm{al}^{24}$ proved that AuNPs as a catalyst can react with the serum in the cell to produce $\mathrm{NO}$ and cause oxidative stress. Because the AuNFs used in this study had a diameter greater than $100 \mathrm{~nm}$, which obstructed their entry of the cell, and the electrokinetic potential (zeta potential) measurements (Table S1) showed that zeta potentials became smaller as AuNF size increased, all the implications of the larger size decrease the toxicity of the AuNFs to the cells. However, the

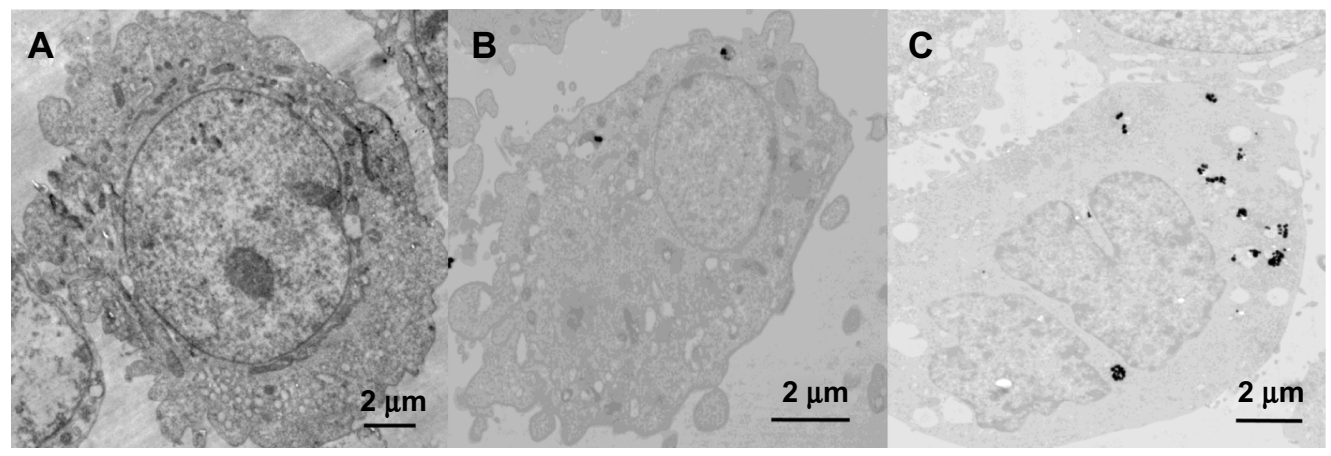

Figure 7 (A-C) TEM images of the HeLa cells. (A) Control sample; (B) HeLa cells treated with Au nanoflowers (AuNFs; I53 nm) after 24 hours without near-infrared (NIR) irradiation; and (C) HeLa cells treated with AuNFs ( $153 \mathrm{~nm})$ after 24 hours with NIR irradiation $\left(\lambda=808 \mathrm{~nm}, 9 \mathrm{~W} / \mathrm{cm}^{2}, 5 \mathrm{minutes}\right)$. 


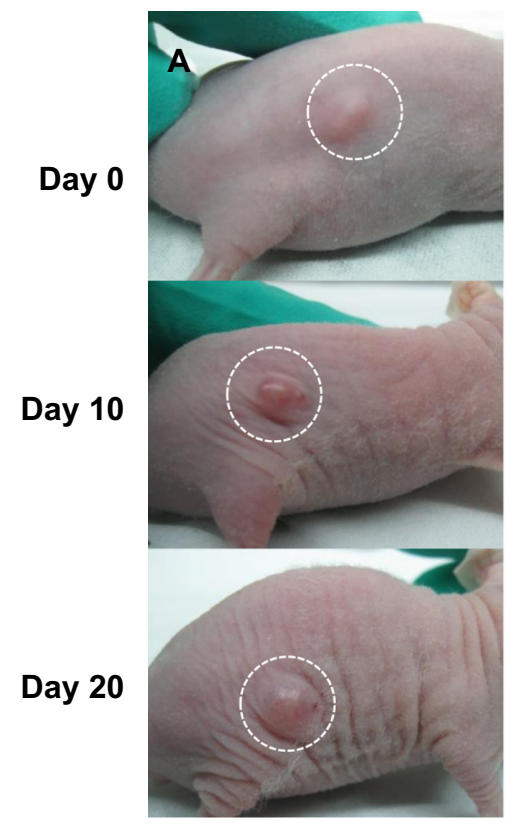

Under irradiation without AuNFs

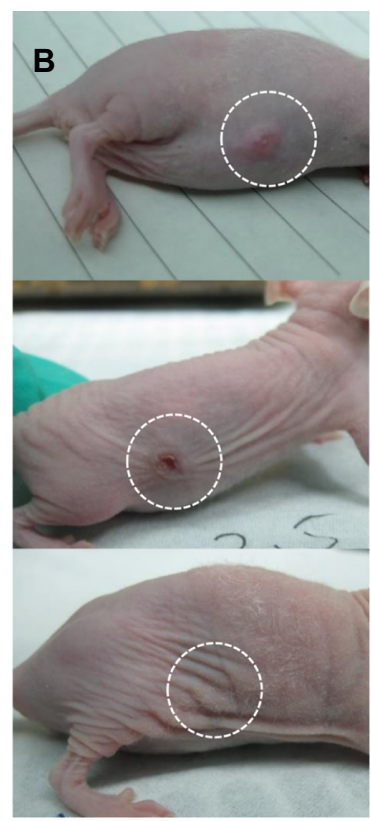

Under irradiation with AuNFs

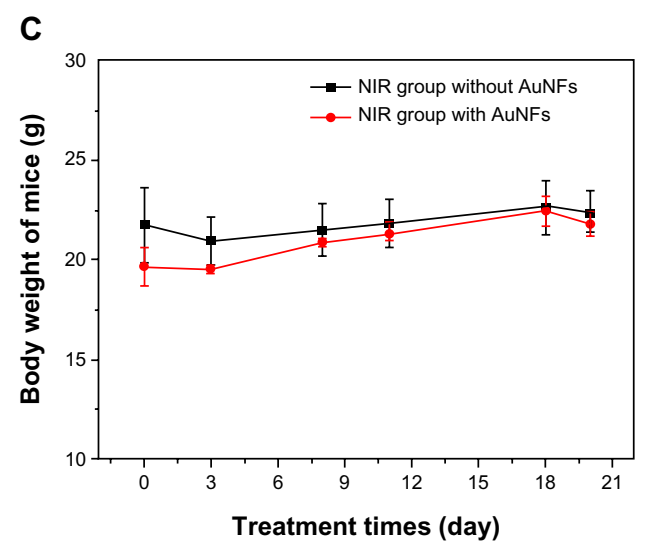

Figure 8 (A-C) Photothermal therapy effect on nude mouse under near-infrared (NIR) irradiation caused by the addition of Au nanoflowers (AuNFs). (A) HeLa tumorbearing Balb/c nude mouse treated without addition of AuNFs; (B) HeLa tumor-bearing Balb/c nude mouse with the addition of AuNFs; (C) body weight change of mice with treatment time. Both experiments were performed under $808 \mathrm{~nm}$ NIR laser irradiation.

photothermal effect increased the temperature, facilitating the internalization of AuNFs and killing the cancer cells..$^{20,25}$ According to these experiments, the most interesting result is that when the size of the AuNFs increased, both the biosafety and cytotoxicity of the AuNFs to the cancer cells increased. A schematic diagram representing the proposed mechanism is shown in Figure 9. Nevertheless, the real mechanism for the larger size nanoparticles interaction with cells is still not clear. ${ }^{26,27}$ Since this is a complicated system, we will perform all the necessary experiments in future to explore the exact mechanism of this important phenomenon at the molecular level.

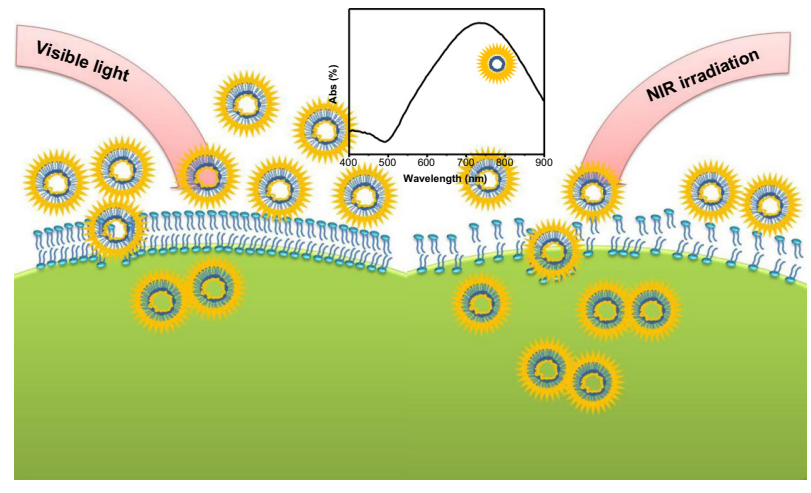

Figure 9 Schematic representation showing the photothermal effect of the Au nanoflowers on endocytosis under near-infrared (NIR) irradiation. 


\section{Conclusion}

In conclusion, we have successfully fabricated a special type of AuNF with no solid core and a diameter larger than $100 \mathrm{~nm}$. The endocytosis and cytotoxicity of AuNFs related to the sizes and photothermal effects of the AuNFs have been studied in detail. It was demonstrated that this type of AuNF did not exhibit toxicity to HeLa cells under visible light, but exhibited significant photothermal ablation after NIR irradiation in vitro. The results indicate that as the size of the AuNPs increased, biosafety under visible light improved and cytotoxicity increased under NIR irradiation. The experiments in mice were consistent with the results obtained in vitro. This work is of fundamental importance for the application of AuNPs in cancer therapy. We believe that this type of AuNF can benefit not only HeLa cell therapy but also many other cancer therapies. In addition, the affinity between AuNPs and functional biomolecules, such as aptamers and biomarkers, will make this type of AuNF a good recognition device in cancer diagnosis and therapy.

\section{Acknowledgments}

This research was supported by the National Natural Science Foundation of China (grants 20933007, 91127012, 21161130521, 21021003). The authors thank Professor JB $\mathrm{Li}$ of the Institute of Chemistry, CAS for the help in the measurement of HeLa cell viability.

\section{Disclosure}

The authors report no conflicts of interest in this work.

\section{References}

1. Maltzahn G, Park J, Lin K, Singh N, Bhatia S. Nanoparticles that communicate in vivo to amplify tumour targeting. Nat Mater. 2011;10(7): 545-552.

2. Huang X, El-Sayed IH, Qian W, El-Sayed MA. Cancer cell imaging and photothermal therapy in the near-infrared region by using gold nanorods. J Am Chem Soc. 2006;128(6):2115-2120.

3. Yuan H, Fales AM, Vo-Dinh T. TAT-peptide-functionalized gold nanostars: enhanced intracellular delivery and efficient NIR photothermal therapy using ultralow irradiance. J Am Chem Soc. 2012;134(28): 11358-11361.

4. Liu H, Liu T, Wu X, Li L, Tang F. Targeting gold nanoshells on silica nanorattles: a drug cocktail to fight breast tumors via a single irradiation with near-infrared laser light. Adv Mater. 2012;24(6):755-761.

5. Wang X, Wang C, Cheng L, Lee ST, Liu Z. Noble metal coated singlewalled carbon nanotubes for applications in surface enhanced Raman scattering and photothermal therapy. J Am Chem Soc. 2012;134(17): 7414-7422.

6. Moon HK, Lee SH, Choi HC. In vivo near-infrared mediated tumor destruction by photothermal effect of carbon nanotubes. ACS Nano. 2009;3(11):3707-3713.
7. Chen Y, Chen H, Sun Y, Zheng Y, Shi J. Multifunctional mesoporous composite nanocapsules for highly efficient MRI-guided highintensity focused ultrasound cancer surgery. Angew Chem Int Ed Engl. 2011;50(52):12505-12509.

8. Kim J, Park S, Lee JE, Cho MH, Hyeon T. Designed fabrication of multifunctional magnetic gold nanoshells and their application to magnetic resonance imaging and photothermal therapy. Angew Chem Int Ed Engl. 2006;45(46):7754-7758.

9. Hu KW, Huang CC, Hwu JR, Su WC, Yeh CS. A new photothermal therapeutic agent: core-free nanostructured AuxAg1-x dendrites. Chem Eur J. 2008;14(10):2956-2964.

10. Chen J, Yang M, Zhang Q, Cho EC, Xia Y. Gold nanocages: a novel class of multifunctional nanomaterials for theranostic applications. Adv Funct Mater. 2010;20(21):3684-3694.

11. Chang H, Wu H. Graphene-based nanomaterials: synthesis, properties, and optical and optoelectronic applications. Adv Funct Mater. 2013; 23(16):1984-1997.

12. Gao L, Fei JB, Zhao J, Li H, Li JB. Hypocrellin-loaded gold nanocages with high two-photon efficiency for photothermal/photodynamic cancer therapy in vitro. ACS Nano. 2012;6(9):8030-8040.

13. Ma Y, Liang X, Tong S, Bao G, Dai Z. Gold nanoshell nanomicelles for potential magnetic resonance imaging, light-triggered drug release, and photothermal therapy. Adv Funct Mater. 2013;23(7):815-822.

14. Oldenburg SJ, Averitt RD, Westcott SL, Halas N. Nanoengineering of optical resonances. J Chem Phys Lett. 1998;288(2-4):243-247.

15. Hirsch LR, Gobin AM, Lowery AR, Halas NJ, West JL. Metal nanoshells. Ann Biomed Eng. 2006;34(1):15-22.

16. Liu H, Chen D, Tang F, Teng X, Li Y. Photothermal therapy of Lewis lung carcinoma in mice using gold nanoshells on carboxylated polystyrene spheres. Nanotechnology. 2008;19(45):455101-455107.

17. Burda C, Chen X, Narayanan R, EI-Sayed M. Chemistry and properties nanocrystals of different shapes. Chem Rev. 2005;105(4): 1025-1102.

18. Chithrani BD, Ghazani AA, Chan WC. Determining the size and shape dependence of gold nanoparticle uptake into mammalian cells. Nano Lett. 2006;6(4):662-668.

19. Pan Y, Neuss S, Simon U, Jahnen-Dechent W, et al. Size-dependent cytotoxicity of gold nanoparticles. Small. 2007;11(3):1941-1949.

20. Chithrani BD, Chan WC. Elucidating the mechanism of cellular uptake and removal of protein-coated gold nanoparticles of different sizes and shapes. Nano Lett. 2007;7(6):1542-1550.

21. Jia W, Li J, Lin G, Jiang L. Two-step synthesis of narrow size distribution nanoflowers using a tree-type multi-amine-head surfactant as a template. Cryst Growth Des. 2011;11(9):3822-3827.

22. Wang W, Lu W, Jiang L. AgCl and $\mathrm{Ag} / \mathrm{AgCl}$ hollow spheres based on self-assemblies of a multi-amine head surfactant. J Colloid Interface Sci. 2009;338(1):270-275.

23. Cui W, Li J, Zhang Ya, Lu W, Jiang L. Effects of aggregation and the surface properties of gold nanoparticles on cytotoxicity and cell growth. Nanomedicine. 2012;8(1):46-53.

24. Jia H, Liu Y, Zhang X, Han L, Xu Y. Potential oxidative stress of gold nanoparticles by induced-NO releasing in serum. $J$ Am Chem Soc. 2008;131(1):40-41.

25. Cho E, Xie J, Wurm P, Xia Y. Understanding the role of surface charge in cellular adsorption versus internalization by selectively removing gold nanoparticles on the cell surface with a I2/KI etchant. Nano Lett. 2009;9(3):1080-1084

26. Zhang X, Wu D, Shen X, Liu P. In vivo renal clearance, biodistribution, toxicity of gold nanoclusters. Biomaterials. 2012;33(18):4628-4638.

27. Duncan R, Pratten M, Lloyd J. Mechanism of polycation stimulation of pinocytosis. Biochim Biophys Acta. 1979;587(3):463-475. 


\section{Supplementary materials}

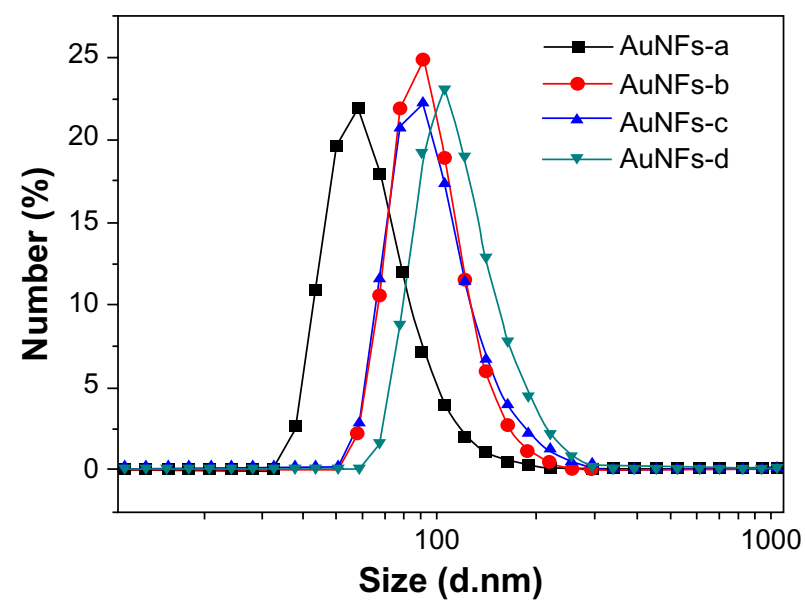

Figure SI Dynamic light-scattering curve of the $A u$ nanoflowers (AuNFs), showing an increase in particle sizes as concentration of growth solution increased: $C_{\mathrm{CI}_{8 N 3}}=0.0625 \mathrm{mM}, \mathrm{C}_{\mathrm{HAuCl} / 4}=0.125 \mathrm{mM}$ (a); $C_{\mathrm{ClINN}}=0.125 \mathrm{mM}$, $\mathrm{C}_{\mathrm{HAuCl} / 4}=0.25 \mathrm{mM}(\mathrm{b}) ; \mathrm{C}_{\mathrm{CI8N3}}=0.1875 \mathrm{mM}, \mathrm{C}_{\mathrm{HAuCl} 4}=0.375 \mathrm{mM}(\mathrm{c})$; and $\mathrm{C}_{\mathrm{CI}_{8 N 3} 3}=0.25 \mathrm{mM}$, $\mathrm{C}_{\mathrm{HAuCl} / 4}=0.5 \mathrm{mM}(\mathrm{d})$.

Abbreviation: $\mathrm{Cl} 8 \mathrm{~N} 3$, bis(amidoethyl-carbamoylethyl) octadecylamine.
Table SI Zeta potential of Au nanoflowers (AuNFs)

\begin{tabular}{|c|c|c|c|c|}
\hline $\begin{array}{l}\text { Sample } \\
\text { name }\end{array}$ & $\begin{array}{l}\text { AuNFs-a } \\
(\text { (II5 nm) }\end{array}$ & $\begin{array}{l}\text { AuNFs-b } \\
(126 \mathrm{~nm})\end{array}$ & $\begin{array}{l}\text { AuNFs-c } \\
(145 \mathrm{~nm})\end{array}$ & $\begin{array}{l}\text { AuNFs-d } \\
(\text { (153 nm) }\end{array}$ \\
\hline Zeta potential & $+24.6 \mathrm{mV}$ & $+18.0 \mathrm{mV}$ & $+15.9 \mathrm{mV}$ & $+11.3 \mathrm{mV}$ \\
\hline
\end{tabular}

Notes: The average sizes of the AuNFs were $115 \mathrm{~nm}$ (a), $126 \mathrm{~nm}$ (b), $145 \mathrm{~nm}$ (c), and $153 \mathrm{~nm}(\mathrm{~d})$.
International Journal of Nanomedicine

\section{Publish your work in this journal}

The International Journal of Nanomedicine is an international, peerreviewed journal focusing on the application of nanotechnology in diagnostics, therapeutics, and drug delivery systems throughout the biomedical field. This journal is indexed on PubMed Central, MedLine, CAS, SciSearch ${ }^{\circledR}$, Current Contents ${ }^{\circledR} /$ Clinical Medicine,

\section{Dovepress}

Journal Citation Reports/Science Edition, EMBase, Scopus and the Elsevier Bibliographic databases. The manuscript management system is completely online and includes a very quick and fair peer-review system, which is all easy to use. Visit http://www.dovepress.com/ testimonials.php to read real quotes from published authors. 